\title{
Walc albo inscenizowanie nowoczesności
}

Wojciech Tomasik 


\section{Przechadzki}

\section{Walc albo inscenizowanie nowoczesności}

Wojciech Tomasik

TEKSTY DRUGIE 2017, NR 4, S. 357-375

DOI: $10.18318 /$ td.2017.4.21

Muzyka i cywilizacja są ściśle z sobą związane. ${ }^{1}$

Joseph Wechsberg Królowie walców

Historia walca zdaje się powtarzać schemat dobrze znany literaturoznawcom z dziejów powieści: forma, która w XIX stulecie wkroczyła jako marginalna, szybko przesunęła się ku kulturowemu centrum i z dzisiejszej perspektywy bardzo wyraźnie rysuje się jako najpopularniejszy gatunek muzyczny tamtego stulecia. Napisałem o formie, że „wkroczyła", ale słowem lepiej oddającym początki jej popularności byłoby inne określenie. Muzykolodzy są zgodni, że prapoczątków tego tańca trzeba szukać w przedalpejskich i alpejskich regionach Niemiec i Austrii, skąd przodek nowoczesnej formy dotarł do Wiednia z załogami łodzi i barek; wiejski lendler do naddunajskiej metropolii najdosłowniej „przypłynął”, wzbudzając zaciekawienie najpierw wśród klientów skromnych zajazdów i gospód, które były zlokalizowane w bezpośrednim sąsiedztwie rzeki, a później wśród wiedeńczyków odwiedzających coraz
Wojciech Tomasik - historyk literatury XIX iXX W., pracownik Uniwersytetu Kazimierza Wielkiego w Bydgoszczy.

Autor książek oraz artykułów w pracach zbiorowych i czasopismach. Opublikował ostatnio: Pociqqg do nowoczesności. Szkice kolejowe (2014), Szalony bieg. Kolej i ciemna nowoczesność (2015), Ikona nowoczesności. Kolej w literaturze polskiej, wyd. 2 (2015), Inżynieria dusz. Literatura realizmu socjalistycznego w planie „propagandy monumentalnej", wyd. 2 (2016).

1 J. Wechsberg Królowie walców. Życie, czasy i muzyka Straussów, przeł. M. Boduszyńska-Borowikowa, PIW, Warszawa 1978. 
modniejsze lokale na Praterze. Poziom wykonawczy wiejskich kapel był niski. Na łodziach i barkach, transportujących w dół Dunaju towary i pasażerów, było miejsce dla niewielkich zespołów, złożonych zazwyczaj z trzech - czterech muzyków nieprofesjonalnych, grających na skrzypcach i gitarach. Muzycy umilali czas spędzany w podróży, a w przerwach popisywali się w nadrzecznych zajazdach, grając do tańca i - równie często - wykonując kawałki przeznaczone tylko do słuchania, tzw. Tafelmusik, muzykę towarzyszącą konsumpcji. Wejście walca w XIX stulecie dokonuje się przez transfer tańca ze wsi do miasta. Pierwszych kompozycji słucha się zatem tam, gdzie tradycyjna kultura wiejska nawiązywała fizyczny kontakt z jej siostrą miejską, tj. w naddunajskiej przestrzeni Wiednia, w dzielnicach peryferyjnych, które - jako część wielkiej metropolii - nie straciły do końca swojej pierwotnej rustykalności².

Jak z początkiem XIX wieku bawiono się i tańczono w podwiedeńskich gospodach i w restauracjach na Praterze? Zapewne tak jak na wsi, skąd rekrutowali się przybyli rzecznymi statkami muzycy-amatorzy. W monografii walca czytamy:

Lendler był tańcem dosyć powolnym i wykonywanym w oddzielnych figurach, jak do dziś jeszcze widzieć można w alpejskich okolicach Austrii i Bawarii. Jego najbardziej charakterystycznymi ruchami były przytupywania i podskoki, od czasu do czasu krok posuwisty. Partnerzy trzymali się w objęciu za ręce lub w talii; od czasu do czasu jedno z tancerzy przechodziło pod ramionami drugiego lub wykonywano inne trudne figury, takie jak przerzucanie kobiety przez plecy mężczyzny - jak w dawnym tańcu volte. Takie figury wymagały rzecz jasna wolnego tempa. Poza tym było zwyczajem tańczyć lendlera na zewnątrz, często na nierównym gruncie, przed gospodą lub na wiejskim placu, a tancerze nosili ciężkie obuwie, takie jak buty lub podkute trzewiki, co wszystko tłumaczy powolną, krzepką i ciężką naturę tego tańca. ${ }^{3}$

2 Wiedzę o walcu czerpię z następujących opracowań: M. Carner The Waltz, Chanticleer Press, New York 1948; J. Wechsberg Królowie walców...; S.H. Yaraman Revolving Embrace. The Waltz as Sex, Steps and Sound, Pendragon Press, Hillsdale 2002; M. Knowles The Wicked Waltz and Other Scandalous Dances. Outrage at Couple Dancing in the 19th Century and Early XX Century, McFarland \& Company, Inc., Publishers, Jefferson 2009; J. Korhonen Social Choreography of the Viennese Waltz. The Transfer and Reception of the Dance in Vienna and Europe, 1780-1825, Finnish Academy of Science and Letters, Helsinki 2014i J. Johnson Out of Time. Music and the Making of Modernity, Oxford University Press, Oxford 2015.

3 M. Carner The Waltz, s. 22; zob. M. Knowles The Wicked Waltz..., s. 46-47. 
W przechodzeniu od pierwotnej formy lendlera do dojrzałej postaci walca trzeba widzieć modernizację tańca. Tę modernizację warto ująć dwojako, skupiając się najpierw na czynnikach zewnętrznych, które pomogły wejść walcowi na europejskie salony, a potem poddając analizie sam taniec, by odpowiedzieć na pytanie, jak ukształtowała się jego relacja z epoką nowoczesności. Kiedy weźmiemy pod uwagę tę relację, okaże się, że nasza wyjściowa analogia nie powinna przysłaniać fundamentalnej różnicy: powieść i walc to dwa gatunki, których stosunek do nowoczesności był krańcowo inny. Powieść obrazowała XIX-wieczne procesy modernizacyjne, walc te procesy inscenizował; powieść „utekstowiła” swą epokę, zestaliła jej kształty i czasowe przebiegi, walc pozwalał nowoczesność w każdym wykonaniu na nowo odgrywać; powieść symbolizowała, walc ucieleśniał - w działaniu, w ruchu tańczących, w fizycznej materii balu.

O transformacji lendlera w walc zadecydował splot wielu czynników, z których każdy mógłby udokumentować postęp dokonujący się w dziedzinie technologii. Lendler tańczony był na zewnątrz, na gołej ziemi i oczywiście za dnia. Walc wymagał obszernych sal balowych, gładkich podłóg i sztucznego oświetlenia. Sale musiały być odpowiednio duże, by pomieścić towarzystwo znacznie liczniejsze niż to, które gromadziły wiejskie potańcówki. Wyobrażenie o wielkości sal balowych, gdzie tańczono m.in. walca, mogą dać karnawałowe statystyki. Z podsumowania warszawskich zabaw z początków 1840 roku dowiadujemy się zatem, co następuje:

Zjazd gości na karnawał do Warszawy był bardzo liczny, wiele domów zajezdnych i hoteli było przepełnionych, a mieszkania po domach prywatnych wszędzie pozajmowane. Zebrania publiczne dochodziły osób 2000, bale resursy liczyły od 300 do 1500 , wieczory na średnim świecie od 150 do 300, a małe zabawy razem po kilkadziesiąt gości. ${ }^{4}$

Jak wyglądał wystrój sal? Jedną z najokazalszych sal balowych w XIX- wiecznej Warszawie mógł się poszczycić gmach ratusza. Czytamy o niej, co następuje:

Piękna sala balowa, słusznie białą zwana, z ozdobnym w płaskorzeźby plafonem, ożywiona jarzącym dokoła światłem, prawdziwie zachwycający przedstawiała widok. W niej to zbierały się przybywające na zabawę

4 "Kurier Warszawski" $1840 \mathrm{nr}$ 78, s. 366-367. 
goście, oczekując na przybycie dostojnych osób. Wgłębi jej umieszczoną była orkiestra, odpowiadająca jakby echo pierwszej, grzmiącej w głównej dwupiętrowej sali. Sala ta, to jest główna, również okazała, upiększona w górze dwoma freskami, przedstawiającymi ucztę, i ścianami zdobnymi w filunki, oświetloną była przez 8 żyrandoli, znaczną liczbę świeczników i rząd światła jarzącego, okalającego gzymsy. W niszy o dwóch kolumnach mieściła się orkiestra, a okna sali, tak jak wszystkich innych, osłaniały draperie z bogatych materii. ${ }^{5}$

Nie wszędzie były sale wielkie i nie wszyscy mogli sobie pozwolić na imponującą iluminację wnętrz. Dziewiętnasty wiek rozpoczyna się pod znakiem oświetleniowego przełomu: od lat 30. produkowane są na masową skalę świece stearynowe, znacznie tańsze niż te, które były wyrabiane z wosku ${ }^{6}$. Przełom w dziedzinie sztucznego oświetlenia, który zadekretowało najpełniej pojawienie się lamp gazowych, w drugiej połowie XIX wieku został wsparty innymi nowinkami technicznymi, pozwalającymi rozwiązać problem rozjaśnienia wnętrz. Żelazne konstrukcje nośne i technologia otrzymywania dużych tafli szklanych umożliwiły wznoszenie obiektów, gdzie w większym stopniu niż wcześniej można było korzystać ze światła naturalnego. Warto pamiętać, że londyński Kryształowy Pałac po zakończeniu wystawy światowej, dla której powstał, został przeniesiony w inne miejsce, stając się wielką salą, gdzie były organizowane m.in. koncerty muzyczne i wystawne bale?

Lendler wykonywany był w strojach, które prawdopodobnie niczym nie różniły się od tych zwyczajnych, wykorzystywanych do codziennych prac polowych. Podobnie rzecz wyglądała z obuwiem. Walca tańczono w strojach przeznaczonych specjalnie do tego celu, przygotowywanych i wkładanych tylko na tę okazję, co w przypadku kobiet oznaczało wystawne toalety i kunsztownie ułożone fryzury. Opis toalet, a przynajmniej najświetniejszych z nich, stanowił niezbywalną część relacji z balów, jakie przynosiła XIX-wieczna warszawska prasa. Składając taką relację z balu sylwestrowego w 1845 roku, anonimowy sprawozdawca nie krył zachwytu strojami tańczących kobiet:

5 "Kurier Warszawski" $1850 \mathrm{nr} 283$.

6 O wspomnianym wcześniej warszawskim karnawale z roku 1840 dowiadujemy się: „Oświecenie salonów kęketami [tj. kinkietami] używanym było; wszędzie zaś iskrzyły się świece woskowe albo stearyny" („Kurier Warszawski" $1840 \mathrm{nr} 78$, s. 366).

7 Zob. M. Musgrave The Musical Life of the Crystal Palace, Cambridge University Press, Cambridge 2005. 
„Był to kwiat kwiatu, w kwieciste z kwiatów uwite przybrane stroje”. I dodawał z żalem:

Jaka szkoda, że sztuka dagerotypowa nie potrafi jeszcze powtarzać przedmiotów światłem sztucznym oświetlonych. Uchwycony tym sposobem obraz wczorajszej zabawy byłby nieocenionym zbiorem doskonałości i piękności. ${ }^{8}$

Parę dekad później sytuacja zmienia się. Postęp technologiczny sprawił, że fotografie można już było zdejmować parom tańczącym w zamkniętych pomieszczeniach, zaś w samej końcówce stulecia wynalazek kinematografu zademonstrował swe wyrafinowanie w utrwalaniu postaci poruszających się - także w tańcu.

Nowoczesna technologia wsparła walca jeszcze inaczej. Dziewiętnastowieczna kariera tego tańca splata się nierozerwalnie z równie efektowną karierą, jaką robią w tym samym czasie fortepian i jego poprzednik, tj. pianoforte. Nie było w muzycznej historii Zachodu innego okresu, w którym jeden instrument osiągnąłby tak dominującą pozycję zarówno wśród kompozytorów-profesjonalistów, jak i wśród wykonawców-amatorów ${ }^{9}$. Fortepian w rozmaity sposób odzwierciedla kulturę swego okresu i rolę, jaką w jej kształtowaniu odgrywały prądy modernizacyjne. Fortepian (pianoforte) to instrument o niebywałej wszechstronności, którą da się zestawić tylko z możliwościami, jakie miały do zaoferowania organy. Współczesny badacz pisze, że była to samowystarczalna, wszystko zdobywająca „maszyna" muzyczna, która pozwalała przenieść brzmienie orkiestry do wnętrz mieszczańskich salonów ${ }^{10}$. Inny badacz, śledzący początki popularności instrumentu, tę myśl wyraził w tytule rozdziału. Rozdział Pianoforte jako orkiestra kameralna

8 „Kurier Warszawski” 1846 nr 1. Inny przykład: „Przy łunie [...] tysiąca świateł, jakimi apartamenty pałacu zabłysły, cudnie odbijały to paradne stroje, to błyszczące kamienie, to różnobarwne liście i kwiaty, to na koniec pełne pogody i wdzięku postacie, to do skromnych róż, to do smagłych lilii zbliżone” („Kurier Warszawski" 1857 nr 42). Karnawałowy bal, jak widać, poprawiał naturę: w środku zimy, w sztucznie rozświetlonych wnętrzach, pysznić się miały wspaniałe kwiaty. Kwiaty i taniec połączył Piotr Czajkowski w klasycznej kompozycji baletowej, w Walcu kwiatów z Dziadka do orzechów (1892).

9 Zob. L. Plantinga The Piano and the Nineteenth Century, w: Nineteenth-Century Piano Music, ed. by R.L. Todd, Routledge, New York 2004, s. 8.

10 Zob. R.S. Winter Orthodoxies, Paradoxes, and Contradictions: Performance Practices In Nineteenth-Century Music, w: Nineteenth-Century Piano Music, s. 17. 
[The Pianoforte as a Chamber Orchestra] otwierają w charakterze motta słowa Hectora Berlioza, który mówił o orkiestrowym potencjale kryjącym się w nowym instrumencie ${ }^{11}$. Wszechstronnością brzmieniową fortepianu zachwycał się m.in. Liszt ${ }^{12}$. Cechę tę doceniali też inni wielcy twórcy XIX wieku; fortepian staje się w tym czasie instrumentem wirtuozów, podziwianych zarówno w kunszcie kompozytorskim, jak i w maestrii wykonań.

Jako instrument wirtuozów fortepian stanowił zarazem mocny dowód dokonującego się demokratyzowania kultury muzycznej. Fortepian jest w XIX wieku instrumentem, ale też meblem zdobiącym mieszczańskie salony, przedmiotem mającym świadczyć o umuzykalnieniu domu i o artystycznych ambicjach jego mieszkańców. Gra na domowym instrumencie stanowiła ważny składnik życia towarzyskiego epoki, była też - co zgodnie podkreślają fachowcy - nowym kanałem w XIX-wiecznej komunikacji damsko-męskiej. W grze młodej damy realizowała się strategia „polowania na męża”’3. Poświadczają to także zachowania powieściowych heroin, przekładających swe matrymonialne pragnienia na dźwięki wykonywanych walców. Powieściowe wypadki bardzo często zawdzięczały swą motorykę właśnie temu, że pierwsze próby muzycznej komunikacji kończyły się niepowodzeniem. Tak jest m.in. w Targowisku próżności, gdzie dowiadujemy się o klęsce bohaterki, której popis trafia w próżnię męskiego ucha:

Panie spożyły pomarańcze i wypiły po kieliszku wina, co z reguły stanowiło zakończenie posępnych biesiad w domu pana Osborne'a, a gdy panna Jane dała hasło odejścia, wszystkie powstały i odpłynęły do salonu. Amelia żywiła nadzieję, że Jerzy rychło się tam zjawi. Zaczęła grać jego ulubione (świeżo importowane) walce na wielkim fortepianie o rzeźbionych nogach i skórzanym pokrowcu w salonie położonym dokładnie nad jadalnią. Ale przynęta nie podziałała. Jerzy ogłuchł na tony walca. Muzyka cichła stopniowo i zgnębiona artystka odeszła wreszcie od kolosalnego instrumentu. ${ }^{14}$

11 Zob. R.E.M. Harding The Piano-forte. Its History Traced to The Great Exhibition of 1851, Cambridge University Press, Cambridge 1933, s. 85.

Zob. R.S. Winter Orthodoxies..., s. 17.

Zob. R.L. Todd, Preface to the First Edition, w: Nineteenth-Century Piano Music, s. vii-viii. 
Fortepian służył nie tylko do polowania na męża. Był narzędziem do zdobywania ogłady, wchodzenia w świat i osiągania tam nie tylko towarzyskich sukcesów. Wejście w XIX-wieczną kulturę, podkreślają znawcy, wiodło przez naukę gry na fortepianie. Na miano człowieka kulturalnego mógł zasłużyć ten tylko, kto umiał na fortepianie grać, a przynajmniej fortepianowych kawałków nauczył się słuchać.

Żeby fortepian stał się meblem, musiał dokonać się postęp w technice jego wytwarzania, potrzebne były firmy produkujące instrumenty najwyższej klasy, ale też dostarczające masowo na rynek egzemplarze, których przeznaczeniem było przede wszystkim zdobienie mieszczańskich salonów i zaspakajanie snobistycznych (nie zaś - artystycznych) potrzeb. U Thackeraya czytamy wszakże o wielkim instrumencie, „o rzeźbionych nogach i skórzanym pokrowcu", niczego natomiast nie dowiadujemy się o jego walorach brzmieniowych. Najlepszy to dowód, że fortepiany w XIX-wiecznych salonach ogląda się i podziwia, że składnikiem salonowych „biesiad” nie było wyłącznie słuchanie. Często oglądanie i podziwianie kończyło się słuchaniem, znajdując efektowny finał w grze młodych dam. Kulturę muzyczną XIX wieku, na równi z popularnością fortepianu, charakteryzuje imponujący rozwój edytorstwa muzycznego. Wydawaniem kompozycji, zaaranżowanych na domowy instrument, zajmowały się specjalistyczne oficyny, prześcigające się bogactwem oferty i szybkością druku ${ }^{15}$. Liczyła się przede wszystkim szybkość. Dlatego najlepszą rekomendacją dla publikowanego walca było to, że chodzi o dzieło nowe lub najnowsze, które jeszcze niedawno rozbrzmiewało w orkiestrowym wykonaniu - w salach koncertowych Wiednia lub przynajmniej w warszawskich teatrach i „u wód mineralnych warszawskich"16. Komunikacja damsko-męska przybierała w tych wydawnictwach kształt dedykacji. Duża część publikacji ukazywała się bowiem z tytulaturą (często - bardzo bogatą), ze

15 Przeciętny nakład, w jakim w połowie XIX wieku w Warszawie ukazywały się kompozycje muzyczne, wahał się w granicach 200-300 egzemplarzy. Przebój tego czasu, Modlitwa dziewicy Tekli Bądarzewskiej, doczekał się łącznie 900 egzemplarzy (zob. W. Tomaszewski Warszawskie edytorstwo muzyczne w latach 1772-1865, Biblioteka Narodowa. Instytut Książki i Czytelnictwa, Warszawa 1992, s. 80-84).

Zob. J. Strauss (ojciec) Najnowsze walce pod tytułem Huldigungs Walzer skomponowane na piano-forte przez..., grywane w obydwu resursach, Warszawa 1836; tegoż Nowe walce wiedeńskie pod tytułem Rosa Walzer skomponowane na piano forte przez..., grywane u wód mineralnych warszawskich, Warszawa 1836; tegoż Najnowsze walce wiedeńskie pod tytułem Erinnerung an Deutschland skomponowane na pianoforte przez..., grywane w Wielkim Teatrze i u wód mineralnych warszawskich, Warszawa 1836. 
wskazaniem kompozytora i osoby, której rzecz była dedykowana ${ }^{17}$. W większości przypadków nie chodziło o cele matrymonialne. Dedykacja w utworze skomponowanym przez mężczyznę stawała się zazwyczaj eleganckim ukłonem, wyrazem uszanowania czy bezinteresownego zachwytu. Wskazana w dedykacji dama przewidziana była jako szczególna, bo wyróżniona w tytulaturze edycji, wykonawczyni utworu.

Wróćmy do walca. Technologiczne wsparcie, jakie od początku XIX wieku taniec dostawał w formie wielkich sal balowych, sztucznego oświetlenia, gładkich podłóg, fortepianu i masowych edycji fortepianowych kompozycji, ułatwiało zmianę, która dokonywała się w samym sposobie tańczenia. O zmianie tej pisze przywoływany wcześniej monografista:

Gładkie woskowane podłogi miejskich salonów i sal balowych oraz lżejsze obuwie i stroje mieszkańców miast wpłynęły na przyspieszenie tempa [...]. Skoki i podskoki okazały się przeszkodą dla szybkiej rotacji, dlatego zastąpione zostały krokami posuwistymi. Ruch taneczny stał się bardziej gibki i płynny; staccato lendlera zmieniło się w glissando walca. W ten sposób stopniowo dochodzono do stylu, w jakim tańczono walca w XIX w., to jest: zaczyna lewa stopa półkrokiem, prawa stopa w poślizgu przesuwa się w tył po łuku, a następnie lewa stopa zamyka półokrąg, jednocześnie tańczący poruszają się wokół pokoju dużym okręgiem. ${ }^{18}$

Oddajmy teraz głos świadkowi przemian obyczajowych, by przekonać się, jak widział on ruch par poruszających się w walcu. Będzie to głos Kazimierza Brodzińskiego, którego rozprawa $O$ tańcach polskich stanowi jedno z ważnych udokumentowań XIX-wiecznej myśli muzycznej. Brodziński obrazował walc jako taniec narodu, który kocha „uniesienia metafizyczne”, dodając:

Koło walcujących wyobrażać się zdaje obrót planet, podwójny bieg odbywających. Stopy, poczynając od koła, wykreślają kwadraty, krzyże, trójkąty. Jest to obraz sfer, szybko i zawsze przebiegających. Walc jest raczej tańcem nadzmysłowego entuzjazmu, który dwie istoty nad ziemskość unosi. [...] Szybko zwracane twarze, żywo przesuwające się pary, które jak

17 Zob. J. Strauss (ojciec) Valse pour pianoforte dédiée à M-me Pauline Wagner, Warszawa 1836; tegoż Valse pour le pianoforte dédiée à M-me Albertine Ochm, Warszawa 1836; tegoż Valse pour pianoforte dédiée à M-lle Eleonore Kasprzycka, Warszawa 1836. 
zjawiska nikną i powracają, wszystko to ma coś mistycznego i powabnego dla młodzieży. ${ }^{19}$

Jak długo walc nasuwał skojarzenia z ruchem planet, tak długo należał do kultury przednowoczesnej, stanowił porcję rustykalności, przeniesioną na miejski grunt. Ludowa geneza walca doskonale harmonizuje z „planetarną” egzegezą jego figur. Jeśli każdy taniec w jakiś sposób odzwierciedla ruchy charakterystyczne dla jego macierzystej społeczności, to ludowy lendler musiał powielać naturalne rytmy przyrody, determinujące w największym stopniu praktyki wiejskiej gromady. Lendler był tańcem wpisanym w porządek wiejskich zajęć, tańczono go, gdy dawała do tego okazję przyroda, gdy uporano się z pracami polowymi, gdy na zabawę na otwartym powietrzu pozwalały jeszcze blaski zachodzącego słońca. Walc nabrał swoich nowoczesnych kształtów dopiero wtedy, gdy tańczono go niejako wbrew naturze, gdy sztuczne światło zapewniało wystarczającą jasność w wielkiej sali balowej lub w mieszczańskim salonie, gdy gładka posadzka i lekkie obuwie pozwalały na szybkie i precyzyjne ruchy ${ }^{20}$. I wreszcie - gdy edukacja muzyczna, za którą odpowiadały domowy fortepian i tanie edycje tańców, dawała gwarancję, że uczestnicy balu będą wiedzieli, jak mają się w walcu poruszać.

W refleksji nad kulturą nie ma zwykle miejsca na precyzyjne datowanie, w historii walca trudno wskazać moment, w którym ludowy z pochodzenia taniec zaczął się przeistaczać w miejską rozrywkę. Głos Brodzińskiego pochodzi z około 1830 roku, co znaczy, że - przynajmniej u nas - proces modernizowania walca przebiegał dość powoli. Rok 1830 to czas dla europejskiej kultury szczególny. We wrześniu ruszyła w Anglii pierwsza publiczna linia kolejowa. Odtąd o drogach żelaznych zaczęło się mówić wszędzie: zarówno tam, gdzie podobne inwestycje miały wkrótce powstać, jak i tam, gdzie

K. Brodziński O tańcach polskich „ "Gazeta Krakowska” 1831 nr 237, s. 960. Podobnie pisał Łukasz Gołębiowski (Gry i zabawy różnych stanów w kraju całym lub niektórych tylko prowincjach...., Warszawa 1831, s. 317-318): „Walc niemiecki - obraz to sfer zawsze i szybko przemijających, zawsze tą samą wracających drogą; podług innych i słusznie może zbliżenie się to miłosne dwóch kochających się osób; taniec ten widzimy i teraz używamy powszechnie".

20 Miejską zabawę jako wyzwanie rzucone naturze znakomicie pokazuje taki oto początek relacji z warszawskiego balu sylwestrowego w 1847 roku: „W chwilach zimowych, kiedy w obumarłej naturze próżno byś szukał tchnienia wiosny, lubych skarbów uroczej przyrody, człowiek w odwiecznej z żywiołami walce stworzył karnawał, drogie owe dni powabnego szaleństwa, drgające tym porywającym niewypowiedzianym życiem, które każe zapomnieć, że były kiedyś i nadejdą jeszcze bogate w skarby wiosna i lato, i że za obrębem tej sztucznej atmosfery groźne dmą zawieje po ściętych mroźnymi kleszczami obszarach" ("Kurier Warszawski” 1848 nr 2). 
na pierwszy pociąg musiano dość długo czekać. Austria należała do tych pierwszych krain. Tu epoka kolei miała się rozpocząć stosunkowo wcześnie, tu także podczas karnawału w 1835 roku można było usłyszeć kompozycję Josepha Lannera Dampf-Walzer. Już w lutym tego roku o nowej kompozycji (której tytuł spolszczono na Walc parowy) mogli dowiedzieć się czytelnicy warszawskich dzienników ${ }^{21}$. Latem 1836 roku wiedeńczycy usłyszeli po raz pierwszy kompozycję Johanna Straussa (ojca) Eisenbahn-Lust-Walzer, a w końcu roku warszawska oficyna Ignacego Klukowskiego wypuściła na rynek Wesoła podróż koleją żelazną w opracowaniu na pianoforte ${ }^{22}$. Dla jasności obrazu dorzućmy teraz inne daty: pierwszy odcinek kolei żelaznej został oddany do użytku w Austrii w połowie listopada 1837 roku; kolej przekroczyła Dunaj, docierając do położonego na Praterze okazałego dworca, z początkiem stycznia 1838 roku; pierwsze pociągi ruszyły z Warszawy dopiero w czerwcu 1845 roku. Można zatem śmiało powiedzieć, że przez kilka miesięcy w Wiedniu podróż koleją odbywało się tylko na niby, kręcąc figury w walcu. W Warszawie inscenizowanie podróży kolejowej w tańcu wyprzedzało prawdziwe podróżowanie o prawie dekadę...

Lannerowski Dampf-Walzer był dziełem nowym - z dwu przynajmniej względów. Po pierwsze wprowadzał schemat, który stał się później bardzo popularny. Kompozycję otwiera wolna introdukcja, po której następuje sekwencja pięciu walcowych kawałków. Całość kończy się kodą. Nowość polegała także na wprowadzeniu tytułu ${ }^{23}$. Lendlery i pierwsze wzorowane na nich walce nie miały tytułów, pojawienie się tytulatury było bez wątpienia świadectwem modernizacji, a dokładniej - komercjalizowania się kompozycji walcowych. Walc z tytułem oznaczał walkę kompozytora i wydawcy o odbiorcę. Tytuł pozwalał słuchaczowi łatwiej zapamiętać kompozycję, pomagał też zidentyfikować utwór, gdy stawał się on towarem w składzie muzycznym i miał trafiać do rąk wykonawców-amatorów. Formuła tytułowa i kompozycja graficzna z okładki stanowiły często wsparcie dla realizowanego tkanką

„Tej zimy na karnawał w Wiedniu Lanner pisał walce i nazwał je: jeden Walc humorystyczny, drugi Walc parowy" (,Kurier Warszawski 1835 nr 43, s. 232). W 1837 roku Dampf-Walzer w opracowaniu na pianoforte wyszedł w Warszawie drukiem w oficynie Ignacego Klukowskiego (zob. „Korespondent” 1837 nr 161, s. 1; „Kurier Warszawski” 1837 nr 156, s. 766 ).

Zob. anons o balu Buntes aus der Zeit w wiedeńskim dzienniku „Wiener Zeitung” 1836 nr 155 (bal z prawykonaniem walca Eisenbahn-Lust-Walzer odbył się 11 lipca); zob. „Korespondent" 1836 nr 330, s. 2 (o publikacji walca Wesoła podróż koleją żelazną w Warszawie); „Kurier Warszawski” $1836 \mathrm{nr} 335$ (o wykonaniu tego walca przez kwintet Napoleona Kurzątkowskiego). 
brzmieniową programu. Tytuł w końcu mógł dawać stempel świeżości. Formuła Dampf-Walzer potwierdzała, że chodzi o kompozycję współczesną, ściśle splecioną z toczonymi dyskusjami o budowanych właśnie pierwszych odcinkach Kolei Północnej (Nordbahn) i o szansach, jakie dla rozwoju Austrii będzie nieść Kolej Południowa (Sudbahn), z Wiednia do portu w Trieście. Modernizacja oznacza sprzyjający klimat dla wszelkich zmian. Nowoczesny walc był kompozycją na jeden sezon, którą musiała zastąpić rzecz nowa. Lanner i Johann Strauss (ojciec) doskonale zdawali sobie z tego sprawę. Pisali szybko i dużo. Wielu twierdzi, że za szybko i za dużo.

Dampf-Walzer to tytuł zagadka. Historycy kolei bardzo chętnie wpisują tę kompozycję na listę XIX-wiecznych muzycznych utworów kolejowych, tłumacząc zazwyczaj, że tytułowa "para” jest synekdochą kolei i że Lanner jako jeden z pierwszych kompozytorów dostrzegł i utrwalił techniczną nowinkę swoich czasów ${ }^{24}$. Wziąwszy pod uwagę, że epoka Lannerowska zna muzykę programową, Dampf-Walzer dałby się z pewnością słuchać jako utwór, którego pozamuzyczne treści technologiczne podpowiadane są przez tytułowe wyrażenie ${ }^{25}$. Ale zwraca się też uwagę, że utwór w swojej pierwszej edycji został zadedykowany Augustowi Corti, właścicielowi kawiarni na Praterze, i że tytułowa para miała nasuwać skojarzenia z filiżanką świeżo zaparzonej kawy ${ }^{26}$. Wydaje się, że najrozsądniej byłoby uznać, że Lannerowski Dampf-Walzerjest utworem, którego tytuł odsyłał do wiedeńskiego Prateru. Ten zaś w momencie, w którym walc powstał, dymił nie tylko kawą. W 1835 roku Wiedeń znał już inną parę: Dunajem do miasta dopływały bowiem statki parowe.

Rewolucję kulturalną w Wiedniu wywołały nie statki parowe, a lokomotywy. W wiedeńskich tańcach (walcach, galopach i polkach) inscenizowano nie rejsy parowców, a ruch pociągów. Także pociągów, których jeszcze nie widziano. Kiedy rozpoczęła się normalna eksploatacja pierwszych odcinków Kolei Północnej (Nordbahn), nastąpił prawdziwy wysyp kolejowych kompozycji muzycznych. Nowymi walcami lub galopadami kwitowano uruchamianie

24 Zob. B. Neuner Bibliographie der österreischen Eisenbahnliteraturvon de Anfängen bis 1918, band 1, Walter Drews Verlag, Wien 2002, s. 604.

25 Programowość kompozycji tego rodzaju (tj. utworów odsyłających różnymi środkami do sfery nowoczesnej techniki) uszła uwadze polskiego monografisty. W pracy poświęconej muzyce programowej Ryszard Daniel Golianek wyróżnił tylko takie typy inspiracji: twórczość literacką, mity i podania, sztuki piękne, przyrodę i historię oraz idee filozoficzne (zob. R.D. Golianek Muzyka programowa XIX wieku. Idee i interpretacje, Wydawnictwo Naukowe UAM, Poznań 1998, S. 57-79).

26 Zob. B. Vestergård Railway Music, transl. by J. Olde, http://www.naxos.com/mainsite. 
nowych połączeń. Do połowy stulecia na liście utworów, którą otwiera Lannerowski Dampf-Walzer (op. 94) i Straussowski Eisenbahn-Lust-Walzer (op. 89), znalazły się m.in. następujące pozycje, dostępne w wydawanych opracowaniach na fortepian lub pianoforte: Andreasa Nemetza Eisenbahngalopp (op. 20), Johanna Straussa (ojca) Reise-Galopp (op. 85) i Moldau-Klänge (walc; op. 186), Carla Bendla Nordbahn-Walzer (op. 5), Philippa Fahrbacha (ojca) Locomotiv-Galopp (op. 31), Josefa Gungla Eisenbahn-Dampf-Galopp (op. 5) i Tanz-Locomotive (walc; op. 23), Josepha Labitzky'ego Wien-Prager Eisenbahn (polka; op. 101) i Tunnel-Fest-Walzer (op. 132). Druga połowa XIX stulecia przyniosła dalsze kompozycje tego typu, w tym - dziś już klasyczne kawałki Straussów: Johanna (syna) Spiralen (walc; op. 209), Accelerationen (walc; op. 234), Vergnügunszug (szybka polka; op 281) i Express-Polka (op. 311) oraz Edwarda Tour und retour (polka francuska; op.125), Reiselust (polka francuska; op. 166) Bahn frei! (szybka polka; op. 45) i Ohne Bremse (szybka polka; op. 238) ${ }^{27}$.

Muzykolodzy dzielą kompozycje walcowe na dwie zasadnicze grupy: użytkowe, tj. układane z myślą o wykorzystaniu w tańcu, i koncertowe, przeznaczone do słuchania. Podział nie jest ostry, ponieważ utwory wybitnie użytkowe mogły stawać się kompozycjami do wykonań koncertowych. Nim ukazał się drukiem walc Straussa Eisenbahn-Lust-Walzer, Carl Czerny skomponował i zdążył wydać nieprzeznaczony do tańca utwór Eisenbahn-Variationen über Johann Strauss beliebten Eisenbahn-Lust-Walzer (op. 431). Walce, które wychodziły w opracowaniach na fortepian (pianoforte) i które wcześniej wymieniłem, miały rozbrzmiewać $\mathrm{w}$ mieszczańskich salonach - w popisach uzdolnionych panien. Nie ulega kwestii, że wykonania domowe mogły służyć za akompaniament do tańca. I z całą pewnością często służyły. Podstawową formą rozpowszechniania Straussowskich walców były bez wątpienia wykonania domowe, dostarczające oprawy prywatnych spotkań i balów. Walc stylizowany (przeznaczony dla orkiestry lub na fortepian) był formą późniejszą, której nieużytkowe przeznaczenie na ogół wyrażało się w bardziej skomplikowanej i rozbudowanej linii melodycznej. Wszystkie wymienione dotąd kompozycje miały się spełniać w ruchu par. Były utworami muzyki popularnej.

Muzyka popularna jest posłuszna prawom rynku. Jej produkcję regulują czynniki ekonomiczne. Masowość oznacza, że chodzi o kompozycje, które mogły liczyć na błyskawiczny zbyt. W XIX-wiecznej dystrybucji walca istotną rolę odgrywały dwa kanały. O jednym była mowa: taniec okazywał się znakomitym interesem dla wydawców i poszukiwanym towarem. Do

27 Zob. B. Neuner Bibliographie der österreischen..., rozdz. Musicstücke. 
klientów składów muzycznych trafiał nie sam taniec, a utwór w starannym opakowaniu. Jednostką dystrybucji stawała się cała broszura. Były w nim, co oczywiste, nuty, były także pozamuzyczne składowe: okładkę zdobiły tytuł, nazwisko kompozytora, dedykacja, wreszcie - stosowna do tytułu i uczytelniająca program ilustracja. Szybki druk i atrakcyjna cena sprawiły, że o nowych kompozycjach bardzo szybko dowiadywano się w europejskich metropoliach. Wydawniczą ofensywę walca mocno wspierała nowa praktyka dystrybucyjna. Coraz lepiej rozwinięta sieć połączeń kolejowych pozwalała na organizowanie objazdów sławnych orkiestr. W końcu października 1850 roku Warszawę odwiedziła orkiestra pod dyrekcją Johanna Straussa (syna). Cztery lata później Strauss podpisał atrakcyjny kontrakt z właścicielami Kolei Carskosielskiej i przez dwanaście sezonów dawał ze swoją orkiestrą koncerty w foksalu w Pawłowsku. Nowoczesność ukazała się tu z jeszcze innej strony. Koncerty w Pawłowsku dowodziły, że sprawna komunikacja kolejowa wpływa na decentralizację życia muzycznego. I staje się siłą napędową dla karier artystycznych światowego formatu ${ }^{\mathbf{2 8}}$.

W wydanej niedawno książce o udziale muzyki w „tworzeniu nowoczesności" Julian Johnson potraktował Straussowskie walce jako kompozycje, które pomagały estetyzować nowoczesną technologię ${ }^{29}$. Zwrócił przy tym uwagę, że kompozycje te czyniły swymi tytułami odwołania nie do użytkowego wykorzystywania pociągów i do podróży podejmowanych w celach praktycznych, a wskazywały raczej na krótkie przejażdżki dla przyjemności, odbywane tam i z powrotem. Idealnym przykładem zdaje się utwór Johanna Straussa (ojca) Eisenbahn-Lust-Walzer oraz kompozycje synów - Johanna (Vergnügunszug) i Edwarda (Tour und retour i Reiselust). Trasa podróży, którą odwzorowywały Straussowskie kompozycje, układała się w figurę koła. Walc ciągnie swą argumentację Johnson - jest tańcem rotacyjnym, gdzie tańczący wykonują jednocześnie dwa obroty. Jeden to obrót każdej pary wokół własnej osi, drugi to zataczanie przez wirujące pary dużego okręgu po obwodzie balowej sali. Oba te jednocześnie wykonywane ruchy stają się dla tańczących źródłem przyjemnych odczuć somatycznych. Wirujące damy miały stopy ukryte pod długimi krynolinami, co czyniło pracę ich stóp niewidoczną i dawało wrażenie, że ciało tańczącej spoczywa i porusza się na kołach. Skojarzenie z obracającym się kołem nasuwała też każda tańcząca para, której wirowanie, tak jak w przypadku prawdziwego koła, dawało w efekcie przemieszczanie

28 J. Korhonen Social Choreography.., S. 194.

29 Zob. J. Johnson Out of Time..., s. 101-102. 
się w przestrzeni. Walc i krótka przejażdżka, stawia kropkę nad i Johnson, zapewniały poruszającym się ciałom podobnego typu przyjemności.

Trudno mi się zgodzić z przedstawionym tutaj stanowiskiem. Zacznę od wątpliwości dotyczącej doboru materiału, który dał podstawę do sformułowania końcowego wniosku. Dlaczego nowoczesność walca miałyby demonstrować tylko te kompozycje, gdzie w tytule robi się odwołania do przejażdżek? Co z pozostałymi kompozycjami kolejowymi, których tytuły wskazują na długie trasy (Wien - Prager Eisenbahn) lub nawet czynią odwołania do całych kolejowych przedsiębiorstw (Nordbahn-Walzer)? Czy tytuł Bahn frei! rzeczywiście kojarzy się z przejażdżką? W Polsce znano tę kompozycję jako Wolna linia, co znaczyłoby dziś „zielone światło” i jazdę z największą dozwoloną szybkością. Wolna linia swoją melodyką wskazuje na pęd, który osiąga się na kolejowych magistralach. Johnson, analizując udział muzyki w estetyzowaniu technologii, zdaje się nie dostrzegać całego bogactwa twórczości, która była dedykowana rewolucji w transporcie. Powstawały, rzecz jasna, utwory o przejażdżkach, powstawały wszakże utwory o dłuższych podróżach, o szalonym pędzie i gwałtownym przyspieszeniu (Accelerationen), o liniach poprowadzonych bardzo śmiało, w tunelach (Tunnel-Fest-Walzer i Spiralen). Kolejowa część industrialnych kompozycji Straussów jest dziś najlepiej znana, ale nie powinna przyciemniać całego zbioru, nie można zapominać o tym, że walcami sławiono również inne technologiczne zdobycze XIX w.: telegrafy, dynamit, wielkie mosty, pierwsze maszyny elektryczne ${ }^{30}$. A co z innymi walcami, które od kompozycji industrialnych różniły się często tylko tytułem? Czy somatyczna przyjemność, jaką dawał Eisenbahn-Lust-Walzer, różniła się czymś od dawanej przez walc Wilde Rosen, skomponowany przez Johanna Straussa-syna? Johnson stawia tezę, iż ruch wirowy dawał tańczącym ten rodzaj przyjemnego oszołomienia, jaki fundowały przejażdżki pociągiem. Powtórzę: w karnawale 1835 roku, gdy tańczono Dampf-Walzer, i latem 1836 roku, gdy bawiono się do dźwięków Eisenbahn-Lust-Walzer, wiedeńczycy nie mieli jeszcze żadnych doświadczeń kolejowych, z którymi mogliby mierzyć przyjemność tańczenia walca. Taniec najwyraźniej nie wiązał się ze swą epoką przez cyrkularność. Ważniejsza była szybkość i precyzja ruchów.

O szybkości, którą walc osiągnął na wielkomiejskich posadzkach, była już mowa. Szybkość tę dzielił walc z innymi modnymi tańcami XIX wieku, z galopem (galopadą) i polką. Pora przyjrzeć się precyzji, wsłuchując się uważnie

30 Zob. J. Strauss (ojciec) Kattenbrücke-Walzer (op. 4; o wiedeńskim moście łańcuchowym); J. Strauss (syn) Explosions-Polka (op. 43; o dynamicie) i Electro-magnetische Polka (op. 110). 
w głos z epoki, w której tańczenie było niemal synonimem walcowania. Anonimowy świadek karnawałowego balu w warszawskim ratuszu tak objaśniał choreograficzną „reformę":

Na onegdajszym balu w ratuszu grano nowe kontredanse Nowakowskiego, które podobały się powszechnie; wykonano również najświeższe kompozycje walców wiedeńskich. W tańczeniu walca zjawiła się reforma, przejęta już od lat kilku w wielu zagranicznych stolicach. Kawalerowie zapraszają damy do pierwszego, drugiego, trzeciego itd. walca, orkiestra daje sygnał tak jak do innych tańców, a następnie gra walc cały z introdukcją i kodą; wszystkie pary stają w długiej kolumnie albo do koła jak w mazurze, a następnie walcują porządkiem i kolejno po 3, 4, 5 do 6 par, stosownie do obszerności lokalu. Przestający tańczyć stają na końcu kolumny lub na miejscu właściwym w kole, a następujące pary podług przyjętej co do liczby zasady zastępują w tańcu miejsca pierwszych. Kolej taka powtarza się póty, póki koda walca nie zakończy. Po czym formuje się walc nowy. Sposób ten tańczenia jest nieodzownym dla zachowania porządku, zwłaszcza w licznych zabawach znosi zarazem zwyczaj stawania mężczyzn we środku sali, który tyle tańcującym przeszkadza. ${ }^{31}$

Na czym polegała „reforma”, która zawitała w karnawale 1841 roku do Warszawy? Na sposobie tańczenia służącym „dla zachowania porządku”. W sali balowej obowiązywał sztywny plan, narzucany wszystkim tańczącym. W karnawałowych balach, co już wiemy, mogło uczestniczyć parę setek osób. By w takich warunkach móc poruszać się w walcu szybko i płynnie, trzeba było zaprowadzenia „porządku”. Planu poruszania się. Rozkładu jazdy. Współczesny badacz kultury, Karl Schlögel, nazwał kolejowe rozkłady jazdy „protokołami cywilizacji”, wskazując też na inną analogię: rozkłady takie to „choreografie nieskończenie wielu skorelowanych ze sobą poruszenn"32.

W latach 40. XIX wieku Europa tańczy walca, trzymając się rozkładu jazdy. Bal stawał się modelem sprawnie działającego przedsiębiorstwa kolejowego, to zaś stanowiło kwintesencję tych relacji, jakie zawiązywały się w nowoczesnym (czytaj: zurbanizowanym) społeczeństwie. Walc tańczony „po kolei”

31 "Kurier Warszawski” 1841 nr 9, s. 42.

32 K. Schlögel Rozkłady jazdy: protokoły cywilizacji, w: tegoż W przestrzeni czas czytamy. O historii cywilizacji i geopolityce, przeł. I. Drozdowska, Ł. Musiał, posł. H. Orłowski, Wydawnictwo Poznańskie, Poznań 2009, s. 350. 
pozwalał przenieść do wnętrza sali balowej całą metropolię, wraz z charakteryzującą ją złożonością ruchów. Georg Simmel pisał: „technika życia wielkomiejskiego byłaby niemożliwa, gdyby wszystkie czynności i stosunki wzajemne nie były włączone w stały, transsubiektywny schemat czasowy" ${ }^{\prime \prime 3}$. Ruch pociągów, odwzorowywany przez rozkład jazdy, jest najlepiej znanym takiego „schematu” przykładem. Taniec pozwalał zagrać nowoczesność, zainscenizować ją szybkością i precyzją ruchów, synchronizacją wielu poruszających się par. W walcu powtarzano pulsowanie wielkiej metropolii, gdzie musiały bezkolizyjnie krzyżować się setki spraw i interesów, gdzie gęstość rozmaitych indywidualnych przedsięwzięć wymuszała przelotną fizyczną bliskość. W walcu, jak w życiu miejskiej społeczności, nie liczyła się indywidualna wirtuozeria. Ważny był efekt, jaki osiągała tańcząca grupa jako całośćs ${ }^{34}$.

Wrócę teraz do elementu, który w rekonstrukcji wywodów Johnsona celowo pominąłem. Źródło somatycznych przyjemności, których symulację wiedeńczycy będą odnajdywać w walcu, widzi badacz w uruchomionej w 1828 roku na Praterze „miniaturowej kolei”. To stąd, z przejażdżek po ułożonym w okrąg torze, miały pochodzić doznania, które przypominały o sobie parom tańczącym walca. Zdanie, gdzie mowa o „miniaturowej kolei”, nie ma, niestety, przypisu, bardzo trudno zatem zweryfikować wykorzystaną informację. Historia kolei w Austrii zna dwie inicjatywy, które wyprzedziły nadejście epoki kolei.W 1824 roku inżynier Anton von Gerstner ułożył na Praterze dwie doświadczalne nitki szyn, które miały zademonstrować wyższość żelaza jako użytego materiału (jedna z nitek miała tory drewniane). Wagoniki w trakcie prób poruszane były siłą koni ${ }^{35}$. We wrześniu i październiku 1834 roku optyk i przedsiębiorca Peter W.F. Voigländer pokazał na głównej alei Prateru skonstruowany przez siebie wóz parowy ${ }^{36}$. Ani jedno, ani drugie nie było zapewne tym, co Johnson nazwał "miniaturową koleją". Wydaje mi się, że korzystając

Zob. G. Simmel Mentalność mieszkańców wielkich miast, w: tegoż Most i drzwi. Wybór esejów, przeł. M. Łukasiewicz, Oficyna Naukowa, Warszawa 2006, s. 119.

Zob. S.M. Allan Dance: Popular, hasło w: Encyclopedia of the Romantic Era, 1760-1850, vol. 1 i 2 (A-Z), general editor Ch.J. Murray, Routledge, New York 2004, s. 256.

Zob. Próby żelaznych i drewnianych dróg w Austrii, „Monitor Warszawski” 1824 nr 96, s. 536. w Niemczech i ma być użyty do ciągnienia tak zwanego wozu towarzyskiego z Wiednia do Baden. Waży 60 centnarów i może pomieścić 6 osób, a oprócz tego ciągnąć na linie wóz z 15 do 30 osobami. Ma w trzech kwadransach odbyć drogę z Wiednia do Baden; jest na resorach i będąc w ruchu nie czyni żadnego hałasu, a machina mająca siłę 12 koni nie wydaje dymu". 
z jakichś przekazów z epoki, badacz popełnił błąd. W przekazach tych chodziło bowiem najpewniej nie o mały pociagg, lecz o inne urządzenie, podobne do tego, na którym od sierpnia 1840 roku mogli zażywać rozrywki mieszkańcy Warszawy. W Liście z Warszawy na prowincją czy tamy o rozmaitych wielkomiejskich przyjemnościach, a w długim wyliczeniu zjawia się też „przejażdżka na kolei żelaznej”"37. Tę przejażdżkę odbywało się nie na "miniaturowej kolei”, lecz... na karuzeli.

Uruchomioną w sierpniu 1840 roku karuzelę tak oto reklamowała warszawska prasa:

Nim nastąpi pożądana w kraju naszym kolej żelazna, wczoraj używano takowej przejażdżki w miniaturze; jest to rodzaj karuzelu w ogrodzie pani Rembaczewskiej przy ulicy Leszno. Urządzenie z znacznym kosztem wykonane. Za wejście do ogrodu płaci się groszy 10, a za dodaniem 20 groszy można na pięć minut zaabonować obracającą się przejażdżkę; 36 osób obraca się od razu (żaden walc tego nie dokaże).

Notatka tej treści znalazła się na pierwszej stronie dziennika, w dziale informacyjnym. Anons reklamowy, umieszczony na ostatniej stronie tego samego numeru dziennika, dodawał istotne szczegóły:

Dziś i w dni następne w ogrodzie JP. Rembaczewskiej przy ulicy Leszno otworzoną zostanie MASZYNA na KOLEI ŻELAZNEJ, z dwunastą wózkami, na których jednocześnie wozić się może 36 osób. Właścicielka pochlebia sobie, że ten nowy sposób zabawy na zadowolenie Szano[wnej] Publiczności zasłużyć potrafi, bowiem nie szczędziła kosztów na gustowne i bezpieczne urządzenie tej maszyny. Zabawa ta ciągle trwać będzie od godz. $9 \mathrm{z}$ rana do $12 \mathrm{w}$ połud[nie], a od 2 do $10 \mathrm{w}$ wieczór, w czasie której dostać będzie można świeżych potraw i napojów za pomierną cenę. Kurs jeden płacić się będzie gr 20 od osoby. Zaś od wejścia do ogrodu gr. 10. Dzieci do lat 12 wchodzić będą bezpłatnie. ${ }^{38}$

Wiedeński „miniaturowy pociąg” mógł być czymś takim. Nie da się wykluczyć, że Warszawa, dając „przejażdżki w miniaturze”, kopiowała urządzenie, które znane było wcześniej w innych metropoliach i które od 1828 roku

37 Zob. List z Warszawy na prowincja , "Gazeta Warszawska”" $1840 \mathrm{nr} 226$.

38 "Kurier Warszawski” 1840 nr 216 (oba cytaty; podkreślenia - w oryginale). 
bawiło wiedeńczyków na Praterze ${ }^{39}$. O „kolei” pani Rembaczewskiej wiemy bardzo niedużo. Garść szczegółów technicznych pojawiła się dopiero wtedy, gdy przedsięwzięcie splajtowało, a urządzenie stało się przedmiotem licytacji. Z ogłoszeń licytacyjnych dowiadujemy się zatem, że składało się ono z dwunastu koników, przyczepionych do trzyosobowych wózków, które najpewniej poruszały się po torach („kolei żelaznej”) ${ }^{40}$. Nie wiemy, co zapewniało karuzeli napęd, wszystko jednak wskazuje, że nie była to maszyna parowa ${ }^{41}$.

W przywołanych informacjach mowa o walcu, z którym rywalizację karuzela pani Rembaczewskiej wygrywała. A wygrywała także dlatego, że miała do zaoferowania oszołomienie o niespotykanej w tańcu precyzji dawkowania. Można powiedzieć, że przejażdżką na karuzeli rządził szczegółowy „rozkład jazdy", że porządek ruchów osiągnął tu znacznie wyższy poziom niż w salach balowych. Walc i karuzela to zjawiska pokrewne, lokujące się w obszarze kultury popularnej, gdzie ambicje i aspiracje twórców idą na kompromis z apetytami mas. Walca tańczono w Wiedniu, gdy „drogę żelazną” znano tylko z jej wersji karuzelowej. Podobnie działo się w Warszawie. Kolejowe kompozycje wykonywano tu i tańczono, zanim można było poznać somatyczne doznania, które dawało podróżowanie pociągiem. Utwory te zrazu importowano. Po uruchomieniu pierwszych odcinków Kolei Warszawsko-Wiedeńskiej muzyczny import zespolił się z rodzimą twórczością. Dziewiętnastowieczne polskie kompozycje technologiczne nigdy nie przybliżyły się do popularności, jaką cieszyły się kompozycje obce. Pamięć o nich bardzo szybko się ulotniła, dziś są to dziełka kompletnie nieznane. Spora ich część zaginęła. Pisałem dotąd wyłącznie o kompozycjach walcowych. Nie zamierzam jednak bronić tezy, że stanowiły one jakąś muzyczną osobliwość i że nowoczesność (z jej

O karuzelach na Praterze czytamy m.in. w następującej relacji z odwiedzin Wiednia (Opis podróży przez Czechy do Wiednia, we wrześniu i październiku r[oku] z[.][eszłego], przez pewnego Galicjanina, "Gazeta Polska” 1829 nr 9, s. 40): „Tam znowu wesołe gromady wyśpiewują leopoldskie piosnecki, tu żartowniś pobudza do głośnego śmiechu, natłoczone huśtawki unoszą się w powietrze, w licznych karuzelach przy tureckiej muzyce pędzą za sobą romansowe pary, tu się gromadzą ciekawi do optycznych widowisk, tam tłok przy kręgielni, tu śmiech przy kuglarzu, wszędzie wesołość, ochota pośród brzęku szklanek i talerzów...". Wśród wspomnianych tu karuzeli, wiozących "romansowe pary”, mogły być takie, gdzie wózki poruszały się po "drodze żelaznej".

Zob. „Kurier Warszawski” 1842 nr 56, 59, 84, 90, 118, 119.

Miejsce po zlikwidowanym ogrodzie wpisało się jeszcze inaczej w historię warszawskiej industrializacji. W 1860 roku stanął tu młyn parowy, a wraz z nim powstał krótki odcinek kolei żelaznej, „po której wagon odstawia zboże i produkt mlewa” (zob. „Tygodnik Ilustrowany” 1860 nr 18, s. 147). 
szybkością, precyzją i synchronizacją ruchów) inscenizowały jedynie pary tańczące walca. Myślę inaczej. Sądzę, że walc dzielił swe możliwości z innymi tańcami swej epoki, z galopadą i polką przede wszystkim. Zarówno w jednym, jak i w drugim dawało się odgrywać przyspieszone tempo XIX-wiecznej metropolii. Paroksyzm wieku znalazł choreograficzny wyraz w szalonej („piekielnej”) odmianie galopady, którą świat poznawał pod nazwą kankana.

\section{Abstract}

\section{Wojciech Tomasik}

KAZIMIERZ WIELKI UNIVERSITY (BYDGOSZCZ)

The Waltz or the Staging of Modernity

The waltz was the most popular musical genre of the nineteenth century. On the one hand this dance represented a product of modernity, and on the other hand it was an artistic form that allowed to stage the processes of modernization, to play them out in the ballroom. The dancing couples' quick movements demanded precise coordination. They had to happen according to a fixed plan, an "itinerary". The somatic impressions of rotating couples recalled other modernized forms of entertainment, similarly subjected to a rigorous plan: the merry-go-round or the train. The waltz's relationships to modernization (and programme music) was highlighted by the compositions' titles.

\section{Keywords}

waltz, modernization, programme music, popular culture 